University of Nebraska - Lincoln

DigitalCommons@University of Nebraska - Lincoln

Publications, Agencies and Staff of the U.S.

Department of Commerce

U.S. Department of Commerce

$12-2000$

\title{
Utility of North Atlantic Right Whale Museum Specimens for Assessing Changes in Genetic Diversity
}

Howard C. Rosenbaum

Molecular Systematics Laboratory, American Museum of Natural History

Mary G. Egan

Molecular Systematics Laboratory, American Museum of Natural History

Phillip Clapham

National Marine Fisheries Service, NEFSC

Robert L. Brownell Jr.

National Marine Fisheries Service, Southwest Fisheries Science Center, rlbcetacea@aol.com

Sobia Malik

McMaster University

See next page for additional authors

Follow this and additional works at: https://digitalcommons.unl.edu/usdeptcommercepub

Part of the Environmental Sciences Commons

Rosenbaum, Howard C.; Egan, Mary G.; Clapham, Phillip; Brownell, Robert L. Jr.; Malik, Sobia; Brown, Moira; White, Bradley; Walsh, Peter; and Desalle, Rob, "Utility of North Atlantic Right Whale Museum Specimens for Assessing Changes in Genetic Diversity" (2000). Publications, Agencies and Staff of the U.S. Department of Commerce. 80.

https://digitalcommons.unl.edu/usdeptcommercepub/80

This Article is brought to you for free and open access by the U.S. Department of Commerce at DigitalCommons@University of Nebraska - Lincoln. It has been accepted for inclusion in Publications, Agencies and Staff of the U.S. Department of Commerce by an authorized administrator of DigitalCommons@University of Nebraska - Lincoln. 


\section{Authors}

Howard C. Rosenbaum, Mary G. Egan, Phillip Clapham, Robert L. Brownell Jr., Sobia Malik, Moira Brown, Bradley White, Peter Walsh, and Rob Desalle 


\title{
Utility of North Atlantic Right Whale Museum Specimens for Assessing Changes in Genetic Diversity
}

\author{
HOWARD C. ROSENBAUM, ${ }^{*}+₫ \subseteq$ MARY G. EGAN, ${ }^{*}$ PHILLIP J. CLAPHAM, \\ ROBERT L. BROWNELL JR., \SOBIA MALIK,** MOIRA W. BROWN, $† \dagger \neq \ddagger$ \\ BRADLEY N. WHITE, ** PETER WALSH, $†$ AND ROB DESALLE* \\ *Molecular Systematics Laboratory, American Museum of Natural History, 79th Street and CPW, \\ New York, NY 10024, U.S.A. \\ †Wildlife Conservation Society, 2300 Southern Boulevard, Bronx, NY 10460, U.S.A. \\ $\ddagger$ National Marine Fisheries Service, NEFSC, 166 Water Street, Woods Hole, MA 02543, U.S.A. \\ $\S$ National Marine Fisheries Service, Southwest Fisheries Science Center, Box 271, La Jolla, CA 92038, U.S.A. \\ *** Biology Department, McMaster University, Hamilton, ON L8S 4K1, Canada \\ ††Center for Coastal Studies, P.O. Box 1036, Provincetown, MA 02657, U.S.A. \\ 㧊East Coast Ecosystems, Toronto, ON M5A 2T5, Canada
}

\begin{abstract}
We examined six historical specimens of the endangered North Atlantic right whale (Eubalaena glacialis) using DNA isolated from documented baleen plates from the late nineteenth and early twentieth centuries. Sequences from the mitochondrial DNA ( $m$ tDNA) control region from these samples were compared with those from a near-exhaustive survey (269 of approximately 320 individuals) of the remaining right whales in the western North Atlantic Ocean. Our results suggest that there bas been only relatively modest change in maternal lineage diversity over the past century in the North Atlantic right whale population. Any significant reduction in genetic variation in the species most likely occurred prior to the late nineteenth century. One bistorical specimen was from the last documented female capable of propagating one of the maternal lineages in the population today; no females in the existing population have been found to carry this mtDNA haplotype. Analysis of the only specimens from the eastern North Atlantic right whale population ever to be examined revealed that eastern and western North Atlantic right whales may not have been genetically differentiated populations. Loss of gene diversity experienced by North Atlantic right whales over the last century has been modest, and the six decades of protection have been successful in maintaining much of the maternal lineage diversity that was present in the late nineteenth century.
\end{abstract}

Utilidad de los Especímenes de Museo de la Ballena Franca Septentrional Eubalaena glacialis del Atlántico Norte para la Estimación de Cambios en la Diversidad Genética

Resumen: Examinamos seis especímenes históricos de la ballena franca septentrional Eubalaena glacialis del Atlántico Norte, usando ADN aislado de placas de las barbas documentadas de finales de siglo diecinueve y principios del siglo veinte. Las secuencias del ADN mitocondrial (mtADN) de la región control de estas muestras comparadas con aquéllas de una muestra casi exhaustiva (269 de aproximadamente 320 individuos) de las ballenas francas remanentes en el océano Atlántico Norte Occidental. Nuestros resultados sugieren que solo ha habido ligeros cambios en la diversidad del linaje materno a lo largo del siglo pasado. Probablemente, cualquier reducción en la variación genética en las especies ocurrió antes del final del siglo diecinueve. Uno de los especímenes históricos fue de la última bembra documentada capaz de propagar uno de los linajes maternos en la población actual. Ninguna de las hembras en las poblaciones existentes ha sido identificada como portadora de este haplotipo de mtADN. El análisis de los especímenes de la población de ballenas del Atlántico Norte Oriental examinados revelan que las ballenas francas del este y del oeste del Atlántico Norte podrían no haber sido poblaciones genéticamente diferentes. La pérdida de diversidad genética experimentada en las poblaciones de ballena franca del Atlántico Norte a lo largo del siglo pasado

SSemail bcr@amnh.org, brosenbaum@wcs.org

Paper submitted June 23, 1999; revised manuscript accepted February 2, 2000.

This article is a U.S. government work, and is not subject to copyright in the United States. 
ha sido modesta y las seis décadas de protección han sido exitosas en el mantenimiento de la mayoría de la diversidad del linaje materno que estaba presente a finales del siglo diecinueve.

\section{Introduction}

The study of endangered species at the genetic level can often be augmented by the addition of historical samples from museum collections (Thomas et al. 1990; Roy et al. 1994; Cooper et al. 1996; Bouzat et al. 1998; Amato et al. 1999; Glenn et al. 1999; Nielsen et al. 1999). One of the major drawbacks to incorporating genetic information from museum specimens into conservation studies is that often only extremely small sample sizes of the historical material can be obtained. Most museum collections do not hold large numbers of specimens of historical populations, especially for larger organisms such as mammals, and some of the specimens may not be available to geneticists because of their rarity and value. Some, if not most, historical samples in museum collections do not yield DNA of sufficient quantity or quality for molecular analysis.

Recent attempts have been made to directly explore past levels of genetic variability. When DNA from a historical sample differs diagnosably from all extant samples, or if a geographic component of variation is observed, genetic interpretation is straightforward (Thomas et al. 1989; Amato et al. 1999). On the other hand, when historical samples are frequency variants of extant populations, interpretation of results depends highly on sample size (Roy et al. 1994; Bouzat et al. 1998; Glenn et al. 1999; Nielsen et al. 1999). A survey of Whooping Cranes (Grus americana) assessed genetic variation and changes in haplotype frequency between pre- and postbottleneck populations based on 35 museum samples (Glenn et al. 1999). Bouzat et al. (1998) examined a population of greater Prairie Chickens (Tympanuchus cupido) in Illinois that had undergone a population decline. Nielsen et al. (1999) surveyed genetic variation in closely related populations of Atlantic salmon over the past 75 years. When historical sample sizes are extremely small, should one simply give up and not examine the historical samples, or can these small historical samples further contribute to the conservation of endangered species?

The northern right whale (Eubalaena glacialis) is the most endangered of all the great whales. The first large whale to be hunted on a systematic commercial basis, this species was taken in the Bay of Biscay as early as the eleventh century (Aguilar 1986). By the late 1530s, Basque whalers had established a substantial fishery off the Labrador coast of Canada (Cumbaa 1986). This early period of hunting was followed by intensive shore whaling off New England in the seventeenth and eighteenth cen- turies. Hunting continued sporadically into the early part of this century until this species received official protection throughout its range in 1935. Right whales in the western North Atlantic today number approximately 300 individuals, and further decline has been suggested (Kraus 1990; Knowlton et al. 1994; Caswell et al. 1999). The eastern stock of the North Atlantic is almost extinct (Collet 1909; Brown 1976); much of the remaining population was hunted nearly to extinction by Norwegian whalers at the start of the twentieth century. Sightings of right whales in the eastern North Atlantic this century have been sparse, with most documented sightings occurring in the 1920s. Recent sightings have occurred this decade and have revived the discussion of the distinctiveness of eastern and western North Atlantic right whale stocks.

We examined the utility of museum-preserved samples for addressing questions about endangered extant populations when available historical sample sizes are extremely small. We devised two analytical approaches that allowed us to compare levels of genetic variability in historical and extant populations of North Atlantic right whales, and we discuss the limitations of the approaches and their implications for conservation of this species.

\section{Methods}

\section{Samples and Data Collection}

An assessment of genetic diversity in historical right whale populations is possible because of the development of techniques for isolating DNA from small amounts of baleen (Rosenbaum et al. 1997). Briefly, a small piece of baleen $(2 \times 3 \mathrm{~cm})$ was obtained from a single baleen plate from museum specimens (Table 1). Pre-extraction treatment and DNA extraction of museum specimens were performed in a separate laboratory facility that was not in proximity to the laboratory where other tissue extraction, polymerase chain reaction (PCR), or DNA sequencing took place. The appropriate controls, as well as dedicated equipment, supplies, and reagents, were used at all times to eliminate contamination. A survey of museums holding right whale specimens found a total of eight North Atlantic right whale baleen samples from the late nineteenth and early twentieth centuries existing in collections; only six were available for molecular sampling (Patten et al. 1986). Putative right whale baleen samples from the sixteenth century (Cumbaa 1986) 
exist but were unavailable for the present study. Sample authenticity was assured because baleen plates were characterized with chronological and geographical information documented at the time of a whale's demise. We compared the genetic variability of six North Atlantic right whale samples taken a century ago with genetic variation in the remaining extant North Atlantic right whale population in which $84 \%$ of the extant population had been surveyed genetically (Malik et al. 1999).

\section{Numerical Calculation of Lost Haplotypes}

First we used an exact calculation to estimate the probability that haplotypes were lost from the extant population. Haplotypes in the historical population can be placed into one of two categories: haplotypes that persist today and haplotypes that are no longer found in the extant population (which will be referred to respectively as "persistent" and "lost" haplotypes). The objective of this method is to estimate how large the frequency of lost haplotypes might have been, given the frequencies of persistent and lost haplotypes detected in our sample of museum specimens.

To estimate the maximum frequency of lost haplotypes, we first assumed that each museum specimen represented a random draw from the historical population. We also assumed that no new haplotypes have arisen since the museum specimens were taken. Under these assumptions, on any given random draw, the probability of observing an individual with a lost haplotype is equal to the relative frequency of lost haplotypes $\left(p_{1}\right)$ in the historical population. The probability of randomly choosing an individual from the historical population with a persistent haplotype is $1-p_{1}$. In a sample of size $n$, the probability of drawing $k$ individuals with lost haplotypes and $n-k$ individuals with persistent haplotypes is given by the binomial probability

$$
\operatorname{Prob}(x \leq k \mid n)=\sum_{i=0}^{k} C(n, i) p_{1}{ }^{i}\left(1-p_{1}\right)^{n-i},
$$

where $x$ is the random variable indicating the number of lost haplotypes detected in the historical sample. For the case in which all the individuals in the historical sample have persistent haplotypes, this simplifies to

$$
\operatorname{Prob}(0 \mid n)=\left(1-p_{1}\right)^{n} \text {. }
$$

To estimate the maximal frequency of lost haplotypes $\left(p_{1}\right)$ in the historical population, we found a value of $p_{1}$ such that Prob $(x \leq k \mid n) \geq 0.95$. The largest value of $p_{1}$ for Prob $(x \leq k \mid n) \geq 0.95$ (termed $f_{\max }$ ) is in essence the frequency estimate for any possible lost haplotypes that were not detected, which makes the observed data $\geq 95 \%$ probable since the time when the museum specimens once lived. Frequencies of lost haplotypes greater than $f_{\max }$ were rejected with confidence 1 Prob $(x \leq k \mid n)$.

In estimating the change in gene diversity over the last century $\left(\Delta_{D}\right)$, we calculated gene diversity for the extant population $\left(D_{e}\right)$ based on $84 \%$ of individuals sampled genetically as if it were an exhaustive sample (Nei 1987; Weir 1997). The historical population sample is not large enough to provide a robust estimate of the historical haplotype frequency distribution. We therefore assumed that the historical haplotype distribution was nearly the same as the extant haplotype distribution, but with a "tail" of lost haplotypes. We set the size of this tail equal to $f_{\max }$, the frequency estimate that makes the observed data $\geq 95 \%$ probable. Because we could find no good biological basis for choosing the number of lost haplotypes, we examined a range of values (1 to 10). The remainder of the historical distribution was reconstructed by multiplying the frequency for each extant haplotype by $\left(1-f_{\max }\right)$. We then calculated gene diversity for the historical population $\left(D_{h}\right)$ using the reconstructed distribution. The percent change in gene diver-

\begin{tabular}{|c|c|c|c|c|c|c|c|c|c|c|}
\hline \multirow[b]{2}{*}{ Haplotype } & \multirow[b]{2}{*}{ Institution $^{a}$} & \multirow[b]{2}{*}{$\operatorname{Year}^{b}$} & \multirow{2}{*}{$\begin{array}{c}\text { Frequency in } \\
\text { extant population }^{c}\end{array}$} & \multicolumn{7}{|c|}{ Variable nucleotide position ${ }^{d}$} \\
\hline & & & & 15975 & 15976 & 15977 & 15993 & 15994 & 16034 & 16116 \\
\hline A & NMNH & 1885 & 0.279 & A & $\mathrm{T}$ & $\mathrm{C}$ & $\mathrm{T}$ & G & C & A \\
\hline $\mathrm{B}^{e}$ & & & 0.145 & A & $\mathrm{C}$ & $\mathrm{T}$ & $\mathrm{T}$ & A & C & A \\
\hline $\mathrm{C}$ & Cambridge & 1907 & 0.130 & A & $\mathrm{C}$ & $\mathrm{T}$ & $\mathrm{T}$ & A & $\mathrm{T}$ & A \\
\hline $\mathrm{D}$ & BMNH & 1891 & 0.435 & A & $\mathrm{C}$ & $\mathrm{T}$ & $\mathrm{T}$ & A & $\mathrm{C}$ & G \\
\hline $\mathrm{D}$ & NMS & 1910 & & $*$ & $*$ & $*$ & $*$ & $*$ & $*$ & $*$ \\
\hline $\mathrm{D}$ & NMS & 1907 & & $*$ & $*$ & $*$ & $*$ & $*$ & $*$ & $*$ \\
\hline $\mathrm{E}$ & AMNH & 1907 & 0.011 & G & $\mathrm{C}$ & $\mathrm{T}$ & $\mathrm{C}$ & G & $\mathrm{C}$ & A \\
\hline
\end{tabular}

Table 1. Mitochondrial DNA control region haplotypes from historical specimens and the extant population of North Atlantic right whales.

"NMNH, National Museum of Natural History, Smithsonian Institution; Cambridge, Cambridge University Museum (United Kingdom); BMNH, British Museum of Natural History; NMS, National Museum of Scotland; AMNH, American Museum of Natural History.

${ }^{b}$ Documented year the whale was taken.

${ }^{c}$ Malik et al. 1999.

${ }^{d}$ Nucleotide positions correspond to fin whale (Balaenoptera physalus) mitochondrial genome. An asterisk indicates a match to the position directly above.

${ }^{e}$ Not detected in the bistorical sample. 
sity based on a frequency estimate that makes the observed data $\geq 95 \%$ probable is

$$
\Delta_{D}=D_{b}-D_{e} / D_{b}
$$

To test the efficacy of our results by analyzing additional samples had they been available, we numerically solved for values of $p_{1}$ to determine the frequency estimate of lost haplotypes such that the observed data are $\geq 95 \%$. We recalculated historical genetic diversity for a range of possible sample sizes showing haplotypes that are and are not found in the extant population.

\section{Resampling and Probability of Detecting Lost Haplotypes}

Our second method for examining changes in genetic diversity was based on a bootstrap test with haplotypes randomly drawn from the empirical haplotype distribution in the extant population to measure the probability that the historical haplotypes detected reflect the number of haplotypes present in the population a century ago. The resampling procedure was done by determining the probability of observing by chance the specific haplotypes detected in the historical sample if a sample of six were drawn from the current distribution of haplotypes. A replicate consisting of six specimens (the number of historical specimens actually analyzed) was randomly chosen $10^{7}$ times from the distribution of haplotypes in the extant population. The probability of obtaining the same distribution of haplotypes detected in the historical sample is equal to the sum of the replicates that correspond to the observed pattern of haplotypes in the historical sample divided by the total number of replicates.

\section{Results and Discussion}

We isolated the DNA of six historical right whale specimens and generated mitochondrial DNA (mtDNA) control region ( $D$-Loop) sequences using the methods outlined by Rosenbaum et al. (1997). The six historical samples carried four different haplotypes, all of which were still present among the five haplotypes existing in the extant population (Table 1). Although the present sample of historical specimens is small, prohibiting a robust estimate of haplotype frequency distribution in the historical population, we were able to evaluate how much haplotypic variation had been lost over the last century. We did this by making the conservative as- sumption that the historical population had the same haplotype frequency distribution as the extant population but that it possessed an additional "tail" of haplotypes that have subsequently been lost $\left(p_{1}\right)$. The matching of all six historical specimens with extant haplotypes implied that the cumulative frequency of haplotypes in this tail was zero and that the historical population had an estimated $D_{b}=0.695$ (Table 2). Based on the historical haplotypes detected, the maximum frequency of any lost haplotypes given $\operatorname{Prob}(x=0 \mid 6) \geq 0.95$ is $p_{1} \leq 0.085$.

Gene diversity is a good measure of genetic variability for conservation purposes because it estimates both the susceptibility of a population to potentially deleterious inbreeding effects and the future rate at which haplotypes may be lost. When we made the additional assumption that the "tail" distribution contained only a single haplotype and compared the rescaled estimate of historical $\left(D_{b}=0.737\right)$ with current gene diversity $\left(D_{e}=\right.$ 0.695 ), there was a suggested change of $5.7 \%$. Allowing more haplotypes in the tail of the distribution increased the estimate of $\Delta_{D}$ to an asymptote of about $20 \%$. This asymptotic loss of gene diversity assumed the maintenance of a large number of haplotypes (10), each at low frequency (0.0394). It seems unlikely that more than a few haplotypes could persist at a combined frequency of 0.394 .

Our estimates of haplotype and gene diversity loss included all obtainable sources of North Atlantic right whale baleen from the nineteenth and early twentieth centuries known to us (Patten et al. 1986). The framework we present could easily be adapted to the case in which lost haplotypes were found in museum samples. For the right whale historical samples, we numerically determined the frequency of lost haplotypes for an additional $n$ samples varying $x$ such that Prob $(x \leq k \mid n) \geq$ 0.95 . For a total of eight samples, the frequency of lost haplotypes was determined by

$$
\operatorname{Prob}(x \leq 2 \mid 8) \geq 0.95 \text {. }
$$

The two additional documented baleen specimens from North Atlantic right whales that were unavailable for molecular work would not substantially add to the power of the analysis (Table 2). The recalculated estimates for $p_{1}, D_{h}$, and $\Delta_{D}$ using a sample size of eight $(0.111,0.747$, and $7.0 \%$, respectively) did not differ greatly from estimates calculated with six samples.

Our second approach, the resampling analysis, yielded results similar to the exact analysis, for which $p_{1}$ was nu-

Table 2. Estimates of the frequency of lost haplotypes, historical gene diversity, and change in gene diversity between extant and historical North Atlantic right whales.

\begin{tabular}{lrr}
\hline Test $^{*}$ & $\mathrm{p}_{1}$ & $\Delta_{\mathrm{D}}(\%)$ \\
\hline 6 historical samples analyzed & 0.085 & 0.737 \\
6 historical samples analyzed $+n=2$ additional historical samples & 0.111 & 0.747 \\
6 historical samples analyzed $+n=4$ additional historical samples & 0.222 & 0.766 \\
\hline
\end{tabular}

${ }^{*}$ The test considers effects on $\mathrm{p}_{1}, \mathrm{D}_{\mathrm{h}}$, and $\Delta_{\mathrm{D}}(\%)$ bad additional bistorical samples been available or existed. See text for further discussion. 
merically calculated. The probability that all or four of the five haplotypes would be found when haplotypes from six specimens are chosen randomly $10^{7}$ times from the haplotype distribution in the extant population was 0.265 . If the haplotype frequencies from the historical population were similar to the distribution in the extant population, there is a $73.5 \%$ chance that fewer haplotypes would be recovered in our sample of six.

One historical specimen (AMNH \#42752, a female killed in 1907) had the same maternal haplotype as that of the haplotype of lowest frequency (haplotype E, 0.01) in the extant population (Table 1). More important, all three individuals with this haplotype in the extant population were males (Malik et al. 1999), suggesting that this maternal haplotype was the most likely of all five maternal haplotypes to become extinct. There is little effect on the estimate of historical gene diversity when this maternal haplotype is reconsidered as lost from the current population $\left(D_{b}=0.734\right)$. It does, however, lower the estimate of the cumulative frequency of lost haplotypes $\left(p_{1} \leq 0.076\right)$. The museum specimen analyzed here is the last known and only documented female carrying this maternal haplotype.

Norwegian whaling at the turn of the century nearly resulted in extinction of the eastern stock of North Atlantic right whales (Collet 1909; Brown 1976). It is interesting that two individuals taken off Scotland in 1907 and 1910, respectively, and one taken off the west coast of Iceland in 1891, carried the same haplotype as the most common haplotype (haplotype D) in the western North Atlantic. Based on the museum samples, we estimated the minimum frequency of haplotype $D$ in the eastern North Atlantic a century ago. We made this estimate using a model analogous to the one described for the lost haplotype frequency. We estimated the haplotype frequency based on the sample of three specimens that made the observed haplotypes' distribution of $\geq 95 \%$ probable. The minimum frequency of haplotype D for the historical population in the eastern North Atlantic, where three historical specimens were identical to one of the maternal haplotypes in the extant population, was estimated by the exact calculation

$$
\text { Prob }(x \leq 0 \mid 3) \geq 0.95 \text {. }
$$

The smallest value of $p_{1}$ for which Prob $(x \leq 0 \mid 3) \geq$ 0.95 is 0.98 . The minimum frequency for this haplotype in the eastern population, although not entirely representative because of the small sample size, would have been substantially higher than its frequency in the extant western North Atlantic population. The high value of $p_{1}$ for the historical eastern North Atlantic population suggested that haplotype D was the most common haplotype in the eastern North Atlantic a century ago. Given that haplotype D was also the most common in the extant western North Atlantic population, one of the principal hypotheses suggesting that North Atlantic right whales once comprised two genetically distinct stocks was not supported by our analysis (Reeves \& Mitchell 1986). An analysis of differences or similarities in historical haplotype composition or frequency alone is unlikely to uncover significant population structure within an ocean basin. Regardless of the relationship, right whales are no longer a functional element of the eastern North Atlantic ecosystem. (Although the two populations may not have been distinguishable on an evolutionary scale, their different histories following exploitation are the basis for their being considered separate for management purposes.)

Although the precision of our analysis was limited by the fact that only six documented specimens from nineteenth and early twentieth century baleen could be analyzed, substantially larger sample sizes of historical specimens would lead to precise estimates of the proportion of maternal haplotypes or gene diversity lost. If as many as four additional historical samples could be analyzed in addition to the six presented here, the maximum frequency of lost haplotypes would be determined numerically by

$$
\text { Prob }(x \leq 4 \mid 10) \geq 0.95 \text {. }
$$

When we conservatively estimated that as many as four and as few as zero new haplotypes might be found, the maximum frequency of lost haplotypes increased to $0.222\left(D_{b}=0.766 ; \Delta_{D}=9.3 \%\right)$.

Our analysis represents one of the first accounts in which both historical and current levels of genetic variation have been surveyed nearly exhaustively for freeranging cetacean or mammalian populations. A recent study of greater prairie chickens demonstrated that specific alleles at a microsatellite locus had been lost between pre- and post-bottleneck populations (Bouzat et al. 1998). Bouzat et al. (1998) found nine alleles in the historical Illinois population that were not present in the current population, six of which are found in all or some of the current populations outside Illinois. Their results suggest that allelic diversity was lost with population decline over the last century. Similar results were found among pre- and post-bottleneck populations of whooping cranes, in which changes in haplotype frequencies and loss of haplotypes were detected among the museum specimens (Glenn et al. 1999).

Other researchers studying low genetic variability in an exploited population have used comparisons with genetic variation found within sister species or populations to make inferences about loss of genetic diversity and the influence of demographic stochasticity (Hoelzel et al. 1993; Hedrick 1995). A similar approach was used to interpret lack of genetic diversity in North Atlantic right whales (Schaeff et al. 1993, 1997). Although comparing levels of genetic diversity across species may provide insight about differences that exist between species, it is not possible to attribute hypothetical changes in genetic diversity in one species to level of genetic variation in another. There are no benchmarks or standards to measure such an effect across species. 
If the assumptions made in our analyses are accepted as valid, then our results suggest that six decades of protection have been successful in maintaining much of the maternal lineage diversity in North Atlantic right whales from the late nineteenth century. Loss of gene diversity experienced by North Atlantic right whales over the last century has been modest. In light of the recent literature, ours is one of the few studies that did not directly detect a loss of haplotypes in a historical population subject to periods of intense exploitation. Our results are consistent with theories that an extreme bottleneck has not occurred in this population over the last 150 years.

Our findings indicate the need for museums and other institutions to make historical specimens available for genetic sampling so that researchers can more accurately determine if genetic lineages have been lost. Only with larger historical samples can observed trends in genetic variability and their implications for the conservation of extant species be assessed with sufficient rigor. Future comparisons with right whales taken in the sixteenth century (Cumbaa 1986) may reveal whether additional maternal haplotypic variation existed and was subsequently lost because of the intense exploitation by Basque whalers. Alternatively, further study could reveal that North Atlantic right whales have maintained relatively low levels of variation for nearly four centuries.

\section{Acknowledgments}

We thank the Smithsonian Institution, Cambridge University Museum, the British Museum of Natural History, the National Museum of Scotland, and the American Museum of Natural History for access to baleen samples. W. Wheeler and J. Kim gave helpful advice on the statistical analyses. G. Amato, R. Baker, and P. Doukakis provided valuable discussion. M. V. Ashley, G. Meffe, E. Main, J. Carlton, and three anonymous reviewers provided substantive comments that greatly improved the manuscript. Funds for this study were obtained from the U.S. National Marine Fisheries Service, the Massachusetts Environmental Trust, and the Natural Sciences and Engineering Council (Canada).

\section{Literature Cited}

Aguilar, A. 1986. A review of old Basque whaling and its effect on the right whales (Eubalaena glacialis) of the North Atlantic. Report of The International Whaling Commission, Special Issue 10:191-199.

Amato, G., M. G. Egan, G. B. Schaller, R. H. Baker, H. C. Rosenbaum, W. G. Robichaud, and R. DeSalle. 1999. The rediscovery of Roosevelt's barking deer (Muntiacus rooseveltorum). Journal of Mammalogy 80:639-643.

Bouzat, J. L., H. A. Lewin, and K. N. Paige. 1998. The ghost of genetic diversity past: historical DNA analysis of the Greater Prairie Chicken. The American Naturalist 152:1-6.

Brown, S. G. 1976. Modern whaling in Britain and the north-east Atlantic Ocean. Mammal Review 6:25-36.
Caswell, H., M. Fujiwara, and S. Brault. 1999. Declining survival probability and its implications for the North Atlantic right whale. Proceedings of The National Academy of Sciences of the United States of America 96:3308-3312.

Collet, R. 1909. A few notes on the whale Balaena glacialis and its capture in recent years in the North Atlantic by Norwegian whalers. Proceedings of The Zoological Society of London:91-98.

Cooper, A., J. Rhymer, H. F. James, S. Olson, C. E. McIntosh, M. D. Sorenson, and R. C. Fleischer. 1996. Ancient DNA and island endemics. Nature 381:484.

Cumbaa, S. L. 1986. Archaeological evidence of the 16th century Basque right whale fishery in Labrador. Report of The International Whaling Commission, Special Issue 10:187-190.

Glenn, T. C., W. Stephan, and M. J. Braun. 1999. Effects of a population bottleneck on Whooping Crane mitochondrial DNA variation. Conservation Biology 13:1097-1107.

Hedrick, P. W. 1995. Elephant seals and the estimation of a population bottleneck. Journal of Heredity 86:232-235

Hoelzel, A. R., R. J. Halley, S. J. O'Brien, C. Campagna, B. Arnbom, B. LeBoeuf, K. Ralls, and G. A. Dover. 1993. Elephant seal genetic variation and the use of simulation models to investigate historical population bottlenecks. Journal of Heredity 84:443-449.

Knowlton, A. R., S. D. Kraus, and R. D. Kenney. 1994. Reproduction in North Atlantic right whales (Eubalaena glacialis). Canadian Journal of Zoology 72:1297-1305.

Kraus, S. D. 1990. Rates and potential causes of mortality in North Atlantic right whales (Eubalaena glacialis). Marine Mammal Science 6:278-291.

Malik, S., M. W. Brown, S. D. Kraus, A. Knowlton, P. Hamilton, and B. N. White. 1999. Assessment of mitochondrial DNA structuring and nursery use in the North Atlantic right whale (Eubalaena glacialis). Canadian Journal of Zoology 77:1-6.

Nei, M. 1987. Molecular evolutionary genetics. Columbia University Press, New York.

Nielsen, E. E., M. M. Hansen, and V. Loeschcke. 1999. Genetic variation in time and space: microsatellite analysis of extinct and extant populations of Atlantic salmon. Evolution 53:261-268.

Patten, D. R., S. D. Kraus, J. Zoeger, and S.G. Brown. 1986. List of institutions possessing specimens of whales of the family Balaenindae. Report of The International Whaling Commission, Special Issue 10: 20-27.

Reeves, R. R., and E. Mitchell. 1986. American pelagic whaling for right whales in the North Atlantic. Report of The International Whaling Commission, Special Issue 10:187-190.

Rosenbaum, H. C., M. G. Egan, P. J. Clapham, R. L. Brownell, and R. DeSalle. 1997. An effective method for isolating DNA from historic specimens of baleen. Molecular Ecology 6:677-681.

Roy, M. S., D. J. Girman, A. C. Taylor, and R. K. Wayne. 1994. The use of museum specimens to reconstruct the genetic variability and relationships of extinct populations. Experientia 50:551-557.

Schaeff, C. M., S. D. Kraus, M. W. Brown, and B. N. White. 1993. Assessment of the population structure of western North Atlantic right whales (Eubalaena glacialis) based on sighting and mtDNA data. Canadian Journal of Zoology 71:339-345.

Schaeff, C. M., S. D. Kraus, M. W. Brown, J. S. Perkins, R. Payne, and B. N. White. 1997. Comparison of genetic variability of North and South Atlantic right whales (Eubalaena), using DNA fingerprinting. Canadian Journal of Zoology 75:1073-1080.

Thomas, R. H., W. Schaffner, A. C. Wilson, and S. Pääbo. 1989. DNA phylogeny of the extinct marsupial wolf. Nature 340:465-467.

Thomas, W. K., S. Pääbo, F. X. Villablanca, and A. C. Wilson. 1990. Spacial and temporal continuity of kangaroo rat populations shown by sequencing mitochondrial DNA from museum specimens. Journal of Molecular Evolution 31:101-112.

Weir, B. 1997. Genetic data analysis II: methods for discrete population genetic data. Sinauer, Sunderland, Massachusetts. 